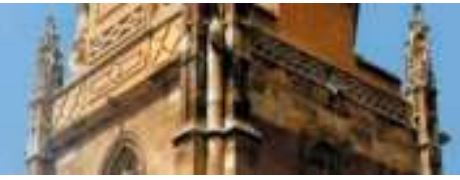

ISSN 1989 - 9572

DOI: 10.47750/jett.2021.12.01.013

\title{
Arab Studies and Arab-Islamic Languages and Research in Imperial Russian Universities: Kazan and St. Petersburg Universities (1804-1855)
}

R.M. Valeev ${ }^{1}$

R.Z. Valeeva ${ }^{2}$

D. R. Khayrutdinov ${ }^{3}$

Journal for Educators, Teachers and Trainers, Vol. 12 (1)

https://jett.labosfor.com/

Date of reception: 05 October 2020

Date of revision: 03 January 2021

Date of acceptance: 02 April 2021

R.M. Valeev, R.Z. Valeeva, D. R. Khayrutdinov (2021). Arab Studies and Arab-Islamic Languages and Research in Imperial Russian Universities: Kazan and St. Petersburg Universities (1804 -1855). Journal for Educators, Teachers and Trainers, Vol. 12(1). 94 - 103.

\footnotetext{
${ }^{1}$ Kazan (Volga region) Federal University, 18, Kremlevskaya Str., Kazan, Russia, 420008

${ }^{2,3}$ Kazan Innovative University named after V.G. Timiryasov (IEML), 42 Moskovskaya Str., Kazan, Russia, 420111
} 


\title{
Arab Studies and Arab-Islamic Languages and Research in Imperial
} Russian Universities: Kazan and St. Petersburg Universities (1804 -1855)

\section{R.M. Valeev ${ }^{1}$, R.Z. Valeeva ${ }^{2}$, D. R. Khayrutdinov ${ }^{3}$}

${ }^{1}$ Kazan (Volga region) Federal University, 18, Kremlevskaya Str., Kazan, Russia, 420008

${ }^{2,3}$ Kazan Innovative University named after V.G. Timiryasov (IEML), 42 Moskovskaya Str., Kazan, Russia, 420111

\begin{abstract}
The authors of this article focus on issues related to history, factors, and trends in the development of Arab-Islamic studies in the Russian Empire. The article presents an overview and systematization of the main events, names, as well as some features of the formation of educational traditions of teaching Arab-Islamic languages, as well as key focus areas and results of historical and cultural studies of Muslim peoples of the Near and Middle East and the Russian Muslim East at Kazan and St. Petersburg Universities in the first half of the 19th century.

Complex academic and university courses and subjects - Arab studies, Iranian studies and Turkology - in the Russian Empire in the first half of the 19th century became important components of the disciplinary and institutional development of modern Oriental studies and are presented as a certain historical, scientific, social and cultural phenomenon of humanitarian research of personas and societies of the Islamic East. These Orientalist fields of research contributed to the knowledge of the national history of Russian state and society, particularly the territories, peoples and cultures of the Empire that were organically connected with the Islamic world.
\end{abstract}

Keywords: Russia, East, Oriental studies, Russian academic Oriental studies, Arab studies, ArabIslamic languages and research.

\section{INTRODUCTION}

In the second half of the 18th - early 20th centuries, Russia saw the development of the system of Oriental studies and the formation of scientific, educational and ideological principles of Arab studies, teaching of Islamic languages and complex Arab-Islamic studies of academics and practitioners. Arab studies, Turkology, and Iranian studies as a set of Islamic disciplines and scientific knowledge, as well as key Orientalist fields related to the history and culture of the Arab-islamic peoples, became an organic sphere of geopolitics, science, and culture of the Russian Imperial state and society.

In the 17th -18 th centuries, the origins of the scholars' acquaintance with the Arab-Islamic civilization were associated with the practical education of translators in the Arab-Islamic languages, the publication of the Arabic text of the Quran in the Catherine II era, as well as the Russian translations of the Holy Book from Western languages and the translation and publication of European texts of "1001 nights" and narratives about "Hagarenes", "Ishmeelites", "Saracens", etc.

Subsequently, original translations of classical Turkic, Arabic and Persian literary monuments appeared. Dictionaries, grammars and language textbooks were compiled and published, and a holistic structural vision of the Arab-Islamic world and the heritage of the peoples of the Arab East was formed. The turn of the 18th - 19th centuries marks the era of the formation of socio-cultural and academic traditions of Arab-Islamic Studies in Russia. This significant milestone was primarily associated with an important component of Russian academic and university orientalism - the systematic and comprehensive teaching and research of the Arabic, Persian and Turkic languages, which played an exceptional role in the study of written and material monuments, as well as with a holistic vision of the historical, geographical and cultural space that the Arab-Islamic civilization occupied.

\section{PROPOSED METHODOLOGY}

In the course of the analysis, the authors of the paper use the main methods and principles of "classical historicism" and "new historicism". Much attention is paid to the communicative and systematic approaches in the study of the formation and development of Arab-Islamic disciplines in Russian universities as a long-term educational and research process, the periodization of Arab studies, Iranian studies, Turkology, their common and specific features, the role of professors and teachers in the development of these Orientalist fields, etc. The 
priority is the comparative method, which allows us to identify the common and special features in the development of Arabic, Iranian studies and Turkology as separate fields of the Russian Oriental studies of the 19th century. Working mainly with narrative sources involved the use of historical-scientific, literary and linguistic analysis. The interdisciplinary approach made it possible to take into account the historiographical, source studies, and historical and cultural aspects of the problems under consideration. Socio-epistemological methodological principles allowed us to substantiate the interdisciplinary relationship and synthesis of university disciplines devoted to the study of Arab-Islamic history and culture, and their role in the formation of objective scientific knowledge about the Islamic East in Russia and Europe.

\section{RESULTS ANALYSIS}

In the 19th - early 20th centuries universities of Imperial Russia, including Kazan University and St. Petersburg University, played an important role in the implementation of the classical model of the "ideal university" and the "university idea" in their social, political, academic and cultural missions [1].

The turning point in the organization of the teaching of Asian languages is quite rightly associated with the policies of Peter I and his decree dated June 18, 1700 on the dispatch of "good-hearted and learned non-elderly monks, two or three people, who could learn Chinese and Mungal language and literacy" to Tobolsk. The official documents show that in $1700-1703$ Peter I sought to establish the teaching of Chinese, Mongolian, Japanese, Syriac, Hebrew, and Chaldean [2, p. 13, p. 63; 15]. In addition to Central and East Asian languages, the official policy of the emerging empire had Semitic and Turkic languages represented as well. Systematizing the important government measures to start training translators of some Arab-Islamic languages, it should be noted that in 1714 - 1715 Peter I instructed to select able students to be included in the embassy of A. P. Volynsky $(1689-1740)^{1}$ to Persia for the purpose of teaching Arabic, Persian, and Ottoman during the mission's stay there.

Oriental studies and orientalism (Arab-Islamic courses and subjects, academic and artistic research) as new humanitarian fields of the Russian university structure were becoming organic in the implementation of the European ideals of a classical university, in the "rise and expansion of science", "increment in scholarly knowledge", in the development of the intellectual capabilities and personal qualities of students, etc. Russian university charters of 1804, 1835, 1863, 1884 developed the institutional bases for the models of classical and applied Oriental studies in the higher educational institutions of Russia.

The trend of academic Oriental studies narrowing and deepening its focus and creating many niche specialties that continued throughout the 19th century was associated with the requirements of the "pure science" of the East, as well as training personnel for state service in the Empire. Arab studies, Turkology, Iranian studies, and Islamic studies - these regional university disciplines and fields at Kazan and St. Petersburg Universities, especially in the 19th and early 20th centuries, were organically intertwined with the geopolitical, social, and cultural development of Imperial Russia. We would like to specifically emphasize that the educational, research and social-cultural system at universities played an important role in diminishing the traditional Europe-centric and imperialist stereotypes about the Islamic East and in dissolving the existing stereotypes about "Asian barbarism", "fanaticism", "Muslim factor", "Pan-Islamism", "Pan-Turkism", "Mohammedan-Tatar influence", "tatarization", "Muslimism", etc.

Academic Oriental studies and Arab-Islamic studies in Russia have demonstrated the contradictions between the university and the imperial government that arose in the process of forming an institutional model of education and science about the East in general and about the Muslim East in particular.

According to the results of the famous "review" made by the trustee of the Kazan School District, M. L. Magnitsky (1778 - 1855; trustee of the Kazan School District in 1819 - 1821), the instructions to the rector of the university dated January 17, 1820 entitled "On Eastern Languages" specifically stated that the teacher had to "confine himself to teaching Arabic and Persian in the only respect in which these languages can be useful for Russia in terms of trade and political relations" [3, p. 56]. So, in 1821 a criminal case against professors was initiated inSt. Petersburg University, and D. P. Runich's reprisal against "unreliable professors" of the university followed. The invited French professors "Charmoy and Demange, as men of honor, avoided participating in the dirty provocation and refused their positions, which led to the fact that since the autumn of 1821, the teaching of Oriental languages went on with long interruptions, and on July 25, 1822, both professors... left the university" [4, p. 145-146]. I. Y. Krachkovsky, assessing the activities of the first Dean of the Oriental Faculty of St. Petersburg University Mirza A. K. Kazem-Bek (1855 - 1859), noted that "his five-year period as the dean was, in fact, a struggle between the practical and scientific bias in the work of the young Faculty, where Kazembek supported the former course" [5, p. 89].

Arab and Arab-Islamic studies in Russia show a certain connection between education and knowledge about the Islamic East on the one hand and imperial power on the other. The imperial state ideology and policy was a determining factor in the institutional development of academic and university Oriental studies in general and the focus areas of studying the peoples of the Arab-Islamic world in the 19th - early 20th centuries. 
During the period under review, the complex humanitarian disciplines devoted to studying the Arab-Islamic civilization demonstrated a comprehensive nature, the breadth of the interdisciplinary approach, an organic combination of philology, history, literature, culture, and religions of the peoples of the East. Their formation and development in Russia were influenced by national, historical, cultural, ethnic, social and psychological factors.

In the first half of the 19th century in Russia, Turkology, Arab studies and Iranian studies that were included in educational programs of universities, acquired an academic, comprehensive and humanist nature. Knowledge and science about the history and culture of the peoples of the Islamic East in Russia were organically linked with intensive historical and cultural contacts, political, state and public interests. In this period, compared to the previous centuries, the development of truly scientific philological and historical-cultural knowledge in Arab-Islamic studies is increasing in academic and university orientalism, new methods and techniques are emerging, and most importantly, the educational, methodological and source base of academic and university orientalism is expanding. The scientific and social significance of Russian Oriental studies and its level were determined by the degree of development of teaching and learning languages of Muslim peoples at universities of Europe and Russia, as well as the qualitative accumulation of objective knowledge about the peoples and states of the Arab-Islamic world, and the interest of the Russian state and society in understanding these academic materials and knowledge. The first half of the 19th century was marked by the formation of institutional structures and centers that did research in languages, literature, poetry, historical and cultural artifacts of the ancient, medieval, and modern history and culture of the Arab-Islamic peoples - Turks, Arabs, Persians, Ottomans, and other Islamic ethnic groups and peoples.

In 1856 the 'Program of the competition for scholars who wish to get the position of an adjunct for Islamic languages and literature in the Imperial Academy of Sciences' (1856) established a list of requirements for applicants. The applicant had to know "(1) thoroughly the following languages: Arabic, Persian, and Turkish, having an equally thorough knowledge of the history and literature of the three main Muslim peoples. It is desirable, moreover, that he should be informed about Semitic languages in General, particularly Syriac and Ethiopian, and be able to use this information in his scientific research. (2) He should have knowledge of antiquities, especially the numismatics of the Muslim peoples. Finally, (3) it is necessary that he should have proper knowledge of the classical languages and of those of the modern ones that are most necessary in order to follow all the learned researches and discourses about the East." ${ }^{2}$ The conditions of the competition also included the submission of the candidate's published works to the conference of the Academy of Sciences.

By the mid-19th century the Kazan and St. Petersburg centers of Oriental studies, which were engaged in ArabIslamic studies, became very important institutions for the history and culture of the peoples of the Volga region and the Urals. The origins of teaching Islamic languages at the universities of Kazan and St. Petersburg testify to the historical-philological and comparative-historical orientation and complexity of research on the history and culture of the foreign Islamic world (Arab countries, the Ottoman Empire, Persia, Turkic-speaking ethnic groups and peoples of the Russian Empire) and the historical and cultural space of "Russian Islam" (the Volga-Ural region, Siberia, the Caucasus, Central Asia and the Crimea).

The origins of the official teaching of Islamic languages in Kazan and in the Empire as a whole are connected with the First Kazan Grammar School (founded in 1758 at Moscow University), where in 1769, taking into account the geographical location and the presence of Turkic-Tatar manuscripts, a class of the Tatar language was created.

On May 12, 1769, two years after visiting Kazan, Empress Catherine II issued a decree to the governor of the Kazan province $(1764-1770)$ A. N. Kvashnin-Samarin $(1716-1775)$ on the opening of the Tatar class in the gymnasium: "...to establish it once and forever at the Kazan Grammar School for enthusiasts of that language and to appoint the interpreter of an old local admiralty office Sagit Halfin as the teacher, who, having been given a rank and salary as an interpreter against the Provincial translator, both himself and his children..." [6, p.45].

The main events that testified to the formation of the tradition of teaching Islamic languages in Russian universities were as follows. For the first time in Russian universities, Arabic began to be studied since 1807 at Kazan University, where it was taught by graduate of a German university, C. Frähn (1782 - 1851). In 1811, Arabic was introduced as a subject at Moscow University. The name and legacy of A. V. Boldyrev (1780 1842) is closely associated with the origins of scientific Arab studies at Moscow University. In the 1820s and 1830s, he prepared and published the first university textbooks on Arab-Islamic languages: "The Arabic Chrestomathy" (Moscow, 1824); "New Arabic Chrestomathy" (Moscow, 1832); "Brief Arabic Grammar" (Moscow, 1st ed., 1827; 2nd ed., 1836); "Persian Chrestomathy" (Moscow, 1st ed., 1826; 2nd ed., 1833).

The origins of European Arab studies are associated with an earlier academic event: in 1538. Guillaume Postel (1510-1581) was appointed the lecturer of Arabic at the Collège royal in Paris [7, P. 26]. In 1538-1543, based on medieval Arabic works, he prepared and published Grammatica Arabica, the first grammar of classical Arabic in Europe. It should also be noted that the first printed book in Arabic was published in 1514 thanks to Pope Julius II, who provided financial support to the Venetian printer Gregorio de Gregori. It was called "The Book of Hours" [8, P. 6]. 
The first half of the nineteenth century in the history of Russian and European orientalism was marked by the beginning of the formation of university Arab studies, Iranian studies, and Turkology, as well as comprehensive cultural and historical studies of the Arab-Islamic civilization.

The opening of the first department of Oriental Languages at the Imperial Kazan University in 1807, mainly focused on the Islamic East, marked a new academic and comprehensive milestone in the history of Russian academic Oriental studies, which ended in 1854/1855 due to the transfer of the Division of Oriental literature and the formation of the Oriental Faculty at St. Petersburg University.

Let us note some of the most important institutional and substantive areas of activity of the first Islamic worldoriented Oriental departments of St. Petersburg University - the departments of Arabic and Persian in 1818/1819 - 1855 and the teaching of Arab-Islamic languages and the study of the Muslim East at Kazan University [9].

Starting from 1819, Arab and Persian literature in St. Petersburg was taught by professors J.-F. Demange (1789 - 1839), F. B. Charmoy (1793 - 1868) and M. D. Topchibashev (1790 - 1869). In 1822, O. I. Senkovsky (1800 - 1858) began teaching Arabic at St. Petersburg University. In 1829 - 1839 B. A. Dorn (1805 - 1881) taught courses in Arab and Persian literature at Kharkiv University, while in 1838-1842 he taught Sanskrit and Afghani at St. Petersburg University.

In 1769 - 1829, one of the most common Islamic languages of the Russian Empire - Tatar - was studied at the First Kazan Grammar School supervised by representatives of the famous Khalfin dynasty (teachers Sagit Khalfin (in 1769 - 1773) and Iskhak Khalfin (in 1773 - 1800)). And from 1800 to 1829 the First Kazan Grammar School and Kazan University had Ibrahim Khalfin (1778 - 1829) as the lecturer of Tatar (1812) and Associate (Adjunct) Professor of Oriental literature (1823) [10]. He became one of the first Tatar scholars and educators to be awarded the title of Associate (Adjunct) Professor of the Imperial University. His name is associated with the creation of textbooks on Tatar grammar and one anthology [11], as well as a joint source work with academician C. Frähn to prepare Genealogy of the Turks" by Abu al-Ghazi for publication [12].

In the 1820s - the first half of the 1830s in the First Kazan Grammar School, the system of teaching ArabIslamic languages was being formed: in 1822, for the first time, the study of Arabic and Persian was officially introduced (taught by F. I. Erdman); in 1826, Mirza Kazem-Bek was appointed as the professor of Islamic languages; in 1827 and 1833, Arabic was taught by I. Vernikovsky; in 1828, A. Onisiforov became the professor of the Tatar language; in $1833 \mathrm{~K}$. Voigt was approved as the professor of the Persian language; in 1835 Mirza Kazem-Bek began teaching the Turkish-Tatar language; in June 1835, according to the report of the Minister of National Education S. S. Uvarov, Nicholas I signed a decree on the introduction of Arabic, Persian, Tatar, Mongolian into the program of the Kazan Grammar School in order to train translators for the departments of the empire, etc. [2, pp. 347-348].

In the 1830 s - 1950s the core faculty was formed for the teaching of Islamic languages to the Grammar School students: in April of 1836, the following people were appointed to the positions of professors and interns of Oriental languages: M. Kazem-Bek (Turkish-Tatar), K. Voigt (Persian), M. Pervukhin (Arabic), N. Sonin (practical classes of Persian), Mullah M. Aliyev (practical classes of Turkish); in January-February of 1843 M.G. Makhmudov was appointed the teacher of Islamic calligraphy. In 1855 he also started teaching the TurkishTatar language; in September of 1845 Abd. Kazem-Bek was appointed supernumerary lecturer of the TurkishTatar language; in 1848, V. Mikhailov (Tatar), K. Popov (Persian), M. Navrotsky (Arabic) were appointed to the positions of teachers, in December of 1852 Ahmet bin Hussein was appointed the supervisor of the Modern Arabic; in the same year, a "class distribution table" was approved for the Oriental languages (Arabic, Persian, Turkish-Tatar, Mongolian, Chinese, Manchu).

In 1830 - 1850, the main methodological programs for Islamic languages were compiled: "Distribution of teaching Arabic, Persian and Turkish-Tatar languages" by F. Erdman, "Distribution of teaching Arabic, Persian and Turkish-Tatar languages" by A. Kazem-Bek.

The theoretical part of teaching Islamic languages in the First Kazan Grammar School included the following provisions: "reading and writing" (4th grade); "detailed presentation of etymology" and "easy translations with careful etymological analysis and explanation" (5th grade); "brief systematic presentation of syntax" and "continuation of translations" (6th grade); "continuation of reading" and "interpretation of difficult translations" (7th grade), etc.

Practical teaching was supposed to orient the supervisors: "reading printed works and manuscripts written in different handwriting, with special supervision of the correct pronunciation" (4th - 5th grades); "composing phrases from memorized words" or "oral translations", as well as "conversations" in Asian languages (5th - 6th grades); "memorizing and reciting selected poetic passages, and exercises in composing private letters and business papers used in the students' dorm" (7th grade), etc.

An important organizational and methodological focus area of learning Asian languages, including Arab-Islamic ones, was the implementation of the idea and principles of practical integration of school and university courses in Oriental languages. This was carried out only at Kazan University in the first half of the 19th century. 
At the beginning of the twentieth century, Kazan University historian N. P. Zagoskin singled out a characteristic feature of the academic departments of the University, noting that "... the Department of Philological Sciences has, due to the exceptional position of Kazan University, an independent department of Oriental languages" [13, p. 11].

In the first half of the 19th century Kazan and Kazan University were becoming a center for the learning and research of Islamic languages and the East in general in Russia and Europe. One of the founders of Kazan University Oriental Studies - expert in Mongolian studies O. M. Kovalevsky in his "Brief review of the progress and success in teaching Asian languages at Kazan University" noted that Kazan "in the last decade... after the capital, became known as the second hotbed of Asian scholarship" [14].

The university charter of November 5, 1804 provided for one professor of Oriental languages and one lecturer of the Tatar language in the Philology Department. By the decree of Alexander I dated July 10, 1807, Doctor of Philosophy and Professor of the University of Rostock C. Frähn (1782 - 1851) was appointed Ordinary Professor of Oriental literature at Kazan University (1807 - 1817).

In 1855 C. Frähn's student P. S. Savelyev wrote the following about his teacher: "There hardly is an orientalist in Russia who does not owe him something... There were knowledgeable orientalists before him at the Academy - the modest Ker and the famous Klaproth, but their works did not even leave any trace in Russian academia, while Frähn instilled his science in the Russian soil and left many followers and successors." 3

German pastor, expert in Hebrew and Exegesis Johann Gottfird (Ivan Bogdanovich) Barendt (? - 1805), invited to Kharkiv University to lecture on Hebrew and the philology of Oriental languages (1803 -1805), and Christian Martin (Christian Danilovich) Frähn, invited to Kazan University, became the first Russian university orientalists from Europe. In the first half of the 19th century it was typical for universities of Kazan, St. Petersburg and Kharkiv to invite graduates of European universities of German and French origin. Moscow University implemented a model of searching for "candidates among Russian youth" and training orientalists in university centers of Europe [15, p. 42].

Official events held in the 19th - early 20th centuries laid the foundation for the formation of the teaching of Islamic languages in Russian universities in general and of comprehensive and purposeful Arab-Islamic studies in Russia and Europe in Kazan and St. Petersburg universities in particular.

The teaching of "Mohammedan languages" and Arab-Islamic studies in the Division of Oriental Literature of Kazan University in 1820 - 1854 was carried out by professors and teachers of the Arab-Persian and the Turkish-Tatar departments, formed on the basis of the original Department of Oriental Literature of the University (1807).

In 1828 two first departments were founded: the Department of Turkish-Tatar Literature, headed until 1846 by A. K. Kazem-Bek (1802 - 1870), and starting from 1846 - by Extraordinary Professor and since 1854 Ordinary Professor I. N. Berezin (1818 - 1896), and the Department of Arab-Persian Literature, which was headed until 1845 by F. I. Erdman (1793 - 1863), in 1846 - 1849 - by A. K. Kazem-Bek, in 1849 - 1855 - by Ordinary Professor I. F. Gottwald (1813 - 1897).

These are just some important facts and processes of the phenomenon of the development of academic disciplines and the disciplinarity of Islamic world-oriented academic Oriental studies in Russia. This specialization was dictated not only by the development of classical Oriental studies, but also by external political and social processes that took place in the relations between Russia, the Islamic East and the West.

The turn of the 18th - 19th centuries marks the era of the birth of cultural and academic traditions of ArabIslamic Studies in Russia. We primarily associate the phenomenon of this milestone with the origins of classical Arab Studies in Russia, a systematic and comprehensive learning of the Arabic, Persian and Turkic languages, their written and material artifacts, and understanding of the classical and modern historical-geographical and ethno-cultural space of the Arab-Islamic heritage.

An important scientific and cultural code of Arab-Islamic studies in Russia in the first half of the 19th century is C. Frähn's work "Chronological list of one hundred works..." (1834)4, "Catalogue of Oriental manuscripts" by Mirza A. K. Kazem-bek (1852) $)^{5}$ and others, which included significant handwritten and printed written legacy of the Arab-Islamic East.

In the middle of the 19th century, Arab studies, Iranian studies, Turkology, and Arab-Islamic studies in general, as a complex of knowledge and research fields of orientalism on the history and culture of Muslim peoples, thanks to the mission of universities, became an organic sphere of domestic science and culture of the Russian state and society.

The countries of the foreign Islamic world - the Ottoman Empire, Persia, the Arab East and the regions of the traditional distribution of Islam in the Russian Empire (the Volga region and the Urals, the Caucasus and Central Asia, the Crimea) have become the object of research in the books and papers written by Kazan and St. Petersburg university orientalists.

In 1829 Mirza A. Kazem-Bek delivered a speech at the Assembly Meeting of Kazan University, called "A Speech on Persian Poetry", written in Farsi, in which he noted: "The subject of your humble servant's speech, which is going to be hereby presented to the attention of the knowledgeable gentlemen, concerns poetry in the 
Persian language. Both my effort and my desire are such as to acquaint you with excerpts from it in a language that is a priceless pearl of expressiveness, perfection and elegance, especially considering that today Oriental languages have become quite popular among Europeans, and many of the great people of the state and gentlemen of academia have turned their eyes in their direction" [16, p. 478].

At the new milestone of the reorganization of university oriental studies in Russia, in 1855, one of the official documents of Kazan University reported: "The main and essential need of the region, for which Kazan serves as the center, is Islamic languages: in this case, the Oriental Faculty at Kazan University, both with respect to its teachers and with respect to its students and textbooks, fully meets all the requirements, propagating, along with practical knowledge of Islamic languages, a thorough and faithful acquaintance with the history and the present situation of the Islamic East..." [17].

This socio-cultural and historical-scientific image of Oriental studies and the prospects of Arab-Islamic studies at Kazan University had a huge impact on improving the scientific and educational image of the university and, in general, on the development of the research of the Islamic East in the history of Russian culture and scientific research of the 19th - early 21 st centuries.

To give a special mention to two representatives who formed the classic scientific and educational image of Kazan and St. Petersburg orientalism of the 19th century, we note: "Christian Danilovich Frähn (ChristianMartin von Frähn, 1782 - 1851) and Alexander Kasimovich Kazembek (Mirza Muhammad Ali Kazem-bek, 1802 - 1870) played an outstanding role in the academic development and institutional formation of Russian orientalism. Having grown and developed as orientalists in Kazan, they made a primary contribution to the formation of the key Oriental institutions of Russia - the Asiatic Museum (now the Institute of Oriental Manuscripts) of the Russian (Imperial St. Petersburg) Academy of Sciences and the Faculty of Oriental Languages (now the Oriental Faculty) of St. Petersburg University" [18, p. 6].

\section{DISCUSSION}

The study of the history of the formation and development of science and discipline about the East and the Arab-Islamic world in Russian and European universities remains relevant at the turn of the 20th - 21st centuries. The phenomenon of the development of regional disciplines of Oriental studies (Turkology, Arab studies, Iranian studies, Islamic studies, Mongolian studies, Chinese studies, etc.), the biographies and heritage of teachers and professors, their contribution and scientific ideas, and other significant aspects of modern Orientalism have been and remain in demand by both professionals and a wider audience of readers.

The teaching of Arab-Islamic languages and the history of the Islamic world is organically interwoven into the history of Russian and foreign Oriental studies and is a very special component of the civilizational and cultural interaction of Russia, the East and the West in modern and contemporary history. Teaching the languages of the peoples of Russia and various Eastern languages in general education secondary schools and universities complied with the needs and interests of the state and society. Comprehensive and systematic research of the history, ethnography, material and written culture of the peoples of the ancient and modern East formed a promising scale of national interests, priority material and spiritual guidelines of the multinational Russian state and society. Oriental studies in Russia played an important role in the development of such substantial components of the national idea as the preservation of the languages and cultures of peoples and ethnic groups; the rights of the individual; the development of geopolitical, political, economic, cultural and intellectual interests; the search for the nation's own place in the world civilization. This humanitarian direction ensured the reinforcement of positive processes in the national consciousness, revealed the historical and cultural aspirations and historical dreams of many peoples of Russia and the East.

In the second half of the 19th century, a new qualitative milestone was marked in the study of the geography, history and culture of Islamic peoples in Russian universities, which was especially clearly manifested in the mission of the Oriental Faculty of St. Petersburg University. The provisions of the new discourse were most fully formulated by A. K. Kazem-Bek in his "Speech on the occasion of the opening of the Faculty of Oriental Languages at St. Petersburg University" (1855). Noting that the emergence of the Oriental faculty was the result of "deliberate governmental concerns and forethought about meeting the needs of science and state interests," Kazem-Bek wrote: "As you may have noticed above, nowhere else in Europe was there such a unity of so many orientalists in one scholarly society as we have now; nowhere were all the branches of Asian languages and literatures so completely concentrated as in our faculty, and, finally, nowhere were there such a number of native representatives of Eastern science and Russian scholars who explored the East on the spot, outside of their homeland, as here." 6 In the history of Russian Oriental studies, this was the beginning of the era of prerevolutionary imperial classical orientalism in particular Arab and Arab-Islamic studies, which lasted until the 1920s and 1930s.

\section{CONCLUSION}

The period from the late 18th to the early 20th centuries was marked by successful development of Asian and African research in Russia and Europe. A cohort of outstanding Russian orientalists who were representatives of 
many peoples of Imperial Russia has provided globally relevant complex philological, historical, archaeological and ethnographic studies in academic and university centers of our country. Oriental studies become an important educational and scientific discipline and area of focus starting from the very beginnings of the university communities of Kazan and St. Petersburg. Lecturers and professors of the "oriental division" of universities in the first half of the 19th century introduced the society to the history and culture of the peoples of both overseas East and the Eastern part of the Empire, as well as expanded the understanding of the phenomenon of cultural legacy of the ancient and modern Asia.

In the history and culture of the peoples of Russia, in particular the historical and cultural area of Volga-Urals, Kazan and St. Petersburg Universities and their schools of humanities and social sciences have played an exceptionally important role.

Research of the history and culture of the peoples of the Islamic world in the universities of Kazan and St. Petersburg in the first half of the 19th century was carried out in the following main areas: preparation and publication of educational programs, manuals, textbooks, anthologies, dictionaries; supplying the library funds with Oriental manuscripts and books; collection, study and publication of written and material Oriental arifacts and sources; translation of texts by Oriental authors; undertaking field research trips to the Islamic East; translated and original philological, historical, cultural, natural-geographical, archaeological and ethnographic publications, etc.

\section{ACKNOWLEDGEMENTS}

This study has been performed under the Russian Government Program of Competitive Growth of Kazan Federal University, RFBR project No 20-09-00385 A.

\section{REFERENCES}

1. See: Bushev, P. P. Posolstvo Artemiya Volynskogo v Iran v 1715 - 1718 gg. (po russkim arkhivam) [The Embassy of Artemiy Volynsky to Iran in 1715 - 1718 (based on Russian archives)]. / Ed. by G. L. Bondarevsky. Moscow, 1978.

2. Programma konkursa dlya uchenyh, zhelayushchih zanyat' v Imperatorskoj Akademii nauk mesto ad"yunkta po chasti musul'manskih yazykov i literatury [Program of the competition for scholars who wish to get the position of an adjunct for Islamic languages and literature in the Imperial Academy of Sciences] // Zhurnal Ministerstva narodnogo prosveshcheniya [Journal of the Ministry of National Education]. - 1856. - Part 89. - Section VII. - P. 66.

3. Savelyev, P. S. O zhizni i nauchnykh trudakh Frena [On the life and scholarly works of Frähn]. St. Petersburg, 1855. Pp. 46, 51.

4. See: Notice chronologique d'une centaine d'ouvrages, pour la plépart historiques et géographiques, tant arabes que persans et turcs, qui manquent en grande partie aux différentes bibliothèques de l'Europe. (Fr.). Frähn, C. Khronologicheskiy spisok sta sochineniy, preimushchestvenno istoricheskogo i geograficheskogo soderzhaniya, na arabskom, persidskom i turetskom yazykakh, nedostayushchikh bolsheyu chastiyu v evropeyskikh bibliotekakh, koikh otyskaniem $\mathrm{v}$ originalakh ili $\mathrm{v}$ vernykh kopiyakh sledovalo by zanyatsya dlya polzy nauk osobam, imeyushchim svoe prebyvanie na Vostoke [Chronological list of one hundred works, mainly of historical and geographical content, in Arabic, Persian and Turkish, which are mostly missing in European libraries, which should be searched for in the originals or in faithful copies for the benefit of the sciences by persons who have their residence in the East]. St. Petersburg, 1834. 24 p. - reprinted in Kazan in 1841.

5. Arabskie rukopisi vostochnogo otdela nauchnoy biblioteki Sankt-Peterburgskogo gosudarstvennogo universiteta: Kratkiy katalog [Arabic manuscripts of the Eastern Department of the Academic Library of the St. Petersburg State University:

6. a brief catalogue] / Comp. by O. B. Frolova and T. P. Deryagina; ed. by O. B. Frolova. St. Petersburg, 1996, etc.

7. Kazem-Bek, A. K. Rech po sluchayu otkrytiya v S.-Peterburgskom universitete fakulteta vostochnykh yazykov, proiznesennaya dekanom onogo, ord. prof. Kazembekom [A speech on the opening of the Faculty of Oriental Language in St. Petersburg University, delivered by its Dean, Ordinary Professor Kazembek] / / Journal of the Ministry of National Education. 1855. P. 88, September. Div. II. Pp. 18-20.

8. Andreev, A. Y. "Ideya universiteta" v Rossii (XVIII - nachalo XX v.) ["The university idea" in Russia (18th - early 20th centuries)] // "Byt' russkim po duhu i evropejcem po obrazovaniyu": Universitety Rossijskoj imperii v obrazovatel'nom prostranstve Central'noj i Vostochnoj Evropy 
XVIII - nachalo XX v. ["Being a Russian in spirit and a European in education": Universities of the Russian Empire and the educational space of the Central and Eastern Europe of the 18th - early 20th centuries] / content by: A. Y. Andreev. Moscow, 2009; Istoriya universitetskogo obrazovaniya $\mathrm{v}$ Rossii i mezhdunarodnye tradicii prosveshcheniya [The History of university education in Russia and the international traditions of education]. Vol. 2. / ed. by: T. V. Artemyeva, M. I. Mieshin. - SPb., 2005; Istoria otechestvennogo vostokovedeniya do serediny XIX veka [The History of Russian Oriental Studies up to the Middle of the 19th Century]. - Moscow, 1990, etc.

9. Kulikova, A. M. Vostokovedenie v rossiyskikh zakonodatelnykh aktyakh (konets XVII v. -1917 g.) [Oriental Studies in Russian legislative acts (late 17th century - 1917)]. -St. Petersburg, 1994.

10. Vysochayshe utverzhdennye v 17 den genvarya 1820 goda dve instruktsii. Rektoru Kazanskogo universiteta, otnositelno $\mathrm{k}$ uchebnomu obrazovaniyu studentov [Highly approved two instructions on the 17th day of January of 1820. To the Rector of Kazan University, regarding the education of students] / / Journal of the Department of National Education. - 1821. - P. 2.

11. Istoriya otechestvennogo vostokovedeniya do serediny XIX veka [History of Russian Oriental studies up to the middle of the 19th century]. - Moscow, 1990.

12. Krachkovsky, I. Y. Ocherki po istorii russkoy arabistiki [Essays on the History of Arab Studies in Russia] / / Selected works. Vol. V. - Moscow - Leningrad, 1958.

13. Vladimirov, V. Istoricheskaya zapiska o 1-y Kazanskoy gimnazii. XVIII stoletie [Historical Note about the 1st Kazan Grammar School. 18th century]. - Kazan, 1867. Part 1.

14. Toomer, G. J. Eastern Wisdom and Learning. The Study of Arabic in Seventeenth-century England. - Oxford, 1996.

15. Hitti, P. K. The First Book Printed in Arabic // The Princeton University Library Chronicle. 1942. - 4 (No 1) (November).

16. See: Valeev, R. M. Orientalistika v Kazanskom universitete (1807 - 20-e gg. XX v.) [Orientalism at Kazan University (1807 - 1920s)]. - Lambert, 2019; Kulikova, A. M. Stanovlenie universitetskogo vostokovedeniya v Peterburge [The formation of academic Oriental studies in St. Petersburg] Moscow, 1982, etc.

17. State Archive of the Republic of Tatarstan (hereinafter - SA RT). coll. 87. aids 1. fol. 8794. "Ob opredelenii uchiteley Kazanskoy gimnazii frantsuzskogo yazyka Leytera i tatarskogo Khalfina lektorami 1-go nemetskogo i poslednego tatarskogo yazykov pri Universitete.7.07.1812 g." ["On the assignment of Kazan Grammar School teachers of the French language Leiter and of the Tatar language Khalfin as lecturers of German (the former) and Tatar (the latter) at the University. 7 July, 1812", 16 sheets; Ibid. coll. 92. aids 1. fol. 1245. "O pribavke zhalovaniya lektoru KHalfinu. 2 aprelya 1820 - 29 aprelya 1820gg." ["On the rise of salary for lecturer Khalfin. April 2, 1820 - April 29, 1820"], 20 sheets; Ibid. fol. 1473. "O vydache lektoru Khalfinu zaimoobrazno 500 rub. 22 avgusta 1821 - 2 sentyabrya 1821 gg." ["On loaning to lecturer Khalfin 500 rubles. August 22, 1821 - September 2, 1821"], 4 sheets; Ibid. fol. 3003. "O smerti adyunkta Khalfina. 25 yanvarya 1829 g." ["On the death of Adjunct Professor Khalfin. January 25, 1829"], 8 sheets; Ibid. fol. 3084. "O proizvodstve vdovam i detyam umershego adyunkta Kazanskogo un-ta KHalfinym pensiy". 19 iyunya 1829 g." ["On the production of pensions to the widows and children of the deceased Adjunct Professor of Kazan University Khalfin". June 19, 1829"] 3 1l.; Ibid. coll. 977. aids Sovet. fol. 176. "Dokumenty o razbore Sovetom universiteta konflikta lektora I. Khalfina s zhenoy. 3 - 21 yanvarya 1814 g." ["Documents on the analysis by the University Council of the conflict between lecturer I. Khalfin and his wife. January 3 - 21, 1814"]. 10 sheets; Ibid. fol. 486. "Perepiska s popechitelem Kazanskogo uchebnogo okruga, predstavlenie lektora I.KHalfina o razreshenii studentam YUnakovu i Bovinu zhit v Tatarskoy slobode dlya prakticheskogo izucheniya tatarskogo yazyka. 20 dekabrya 1819 - 2 marta 1820 g." ["Correspondence with the trustee of the Kazan school district, presentation of the lecturer I. Khalfin on the permission for students Yunakov and Bovin to stay in the Tatar Settlement for practical study of the Tatar language. December 20, 1819 - March 2, 1820"1, 3 sheets.

18. Azbuka i grammatika tatarskogo yazyka, s pravilami arabskogo chteniya [Alphabet and Grammar of Tatar, with the rules of Arabic reading]. - Kazan, 1809; 2nd ed. - Kazan, 1812; Zhizn Dzhingis-khana i Aksak-Timura, s prisovokupleniem raznykh otryvkov, do istorii kasayushchikhsya, koikh vse slova dlya obuchayushchikhsya raspolozheny po alfavitu [The life of Ghenghis Khan and Aksak-Timur, with the addition of various passages related to history, of 
which all the words for students are arranged alphabetically]. - Kazan, 1822; SA RT. coll. 92. aids 1. fol. 46. "O napechatanii Azbuki i Etimologii tatarskogo yazyka, sochinennoy pri Kazanskoy gimnazii. 30 marta 1804 - 12 maya 1804 g." ["On the printing of the Alphabet and the Etymology of the Tatar language, composed at the Kazan Grammar School. March 30, 1804 - May 12, 1804"], 2 sheets.

19. Mazitova, N. A. Izuchenie Blizhnego i Srednego Vostoka v Kazanskom universitete [Studies of the Near and Middle East at Kazan University]. - Kazan, 1972; Valeev, R. Soobrazhayas S obrazom mysley nashey natsii...! [Pondering with the way of thinking of our nation...!] // Gasyrlar avazy - Ekho vekov [Echo of the centuries]. - 1997. - No 1/2. - Pp. 54-61; SA RT. coll. 977. aids Sovet. fol. 679. "Vypiski iz protokolov zasedaniy Soveta i perepiska s popechitelem Kazanskogo uchebnogo okruga, pravleniem i rektorom I.KHalfina o rukopisi Abulgazi Bagadur khana "Istoriya o mongolakh i tatarakh". 5 marta 1821 - 20 sentyabrya 1823 g." ["Extracts from the minutes of Council meetings and correspondence between the trustee of the Kazan School District, the Board and the Rector and I. Khalfin about the manuscript by Abu al-Ghazi Bahadur Khan "The History of the Mongols and Tatars". March 5, 1821 - September 20, 1823", 8 sheets.

20. Zagoskin N. P. Istoriya imperatorskogo Kazanskogo universiteta [History of Imperial Kazan University]. - Kazan, 1902. - Vol. 1.

21. SA RT. coll. 92. aids 1. fol. 5357. sheet 34 .

22. Bartold, V.V. Raboty po istorii vostokovedeniya [Works on the history of Oriental studies] // Sochineniya [Works]: Vol. 9. - Moscow, 1977.

23. Nasledie Mirzy Kazem-Beka: Istoriya i sovremennost: Doklady i soobshcheniya Mezhdunarodnoy nauchnoy konferentsii (g. Kazan, 20-21 noyabrya 2013 g.) [Heritage of Mirza Kazem-Bek: History and modern day: Presentations of the International Academic Conference (Kazan, 20-21 November, 2013). - Kazan, 2014.

24. SA RT. coll. 92. aids 1. fol. 6902. Sheet 57.

25. Epistolyarnoe nasledie rossiyskikh vostokovedov: Pisma Mirzy A.K.Kazem-Beka akademiku KH.D.Frenu (1831-1846) [Epistolary heritage of Russian Orientalists: Letters of Mirza A. K. Kazem-Bek to Academician C. Frähn (1831-1846)]// ed. by R. M. Valeev, translated from English by T. I. Zyapparov, M. V. Ponikarovskaya, prepared for publication, Preface, comments by R. M. Valeev, T. I. Zyapparov, T. V. Kostina, O. A. Kirikova; intr. articles by N. N. Dyakov, I. F. Popova, I. V. Tunkina. Kazan, 2015. 